\title{
Application of extended end composite pile design in pile foundation work
}

\author{
Seungho Kim ${ }^{1} \quad$ Sangyong Kim $^{1} \quad$ Seoung-Wook Whang ${ }^{2} \quad$ Won Gil Hyung $^{1}$ \\ ${ }^{1}$ School of Architecture, Yeungnam University, Gyeongsan-si, South Korea \\ ${ }^{2}$ University of Reading, School of Construction Management and Engineering, Whiteknights, Reading, Berkshire, UK
}

\begin{abstract}
Pre-tensioned, spun, high-strength concrete (PHC) piles are the most commonly used type of pile in South Korea. Approximately $60 \%$ of the pile's strength is used in the design bearing capacity, and the rest is simply residing in the ground. Increasing the ground bearing capacity is crucial to reduce waste of the pile strength and to improve efficiency. Extended end (Ext) piles are a new kind of composite pile that can overcome the weakness of PHC piles. This study investigates the behaviour of Ext piles. Through field testing, it is confirmed that the bearing capacity of Ext piles is better than PHC piles by about $35 \%$ to $50 \%$. Based on the study findings, the Ext pile design reduces the number of piles by around 38\% compared to the PHC pile design through application in a selected construction site. The increased bearing capacity of Ext piles affects both work duration and project cost, which are $25 \%$ and $14 \%$ decreased, respectively.
\end{abstract}

\section{Introduction}

In recent decades, the use of piled foundations has increased due to the building of structures that are larger and higher than before. Pile foundations are principally used to transfer the loads from a superstructure, through weak, compressible strata or water onto stronger, more compact, less compressible and stiffer soil or rock at depth, increasing the effective size of a foundation and resisting horizontal loads (Tomlinson and Woodward, 2014). Piles are generally considered to be a reliable and time-saving method with easy installation in soil to reinforce existing geotechnical structures such as slopes, foundations and excavations ( $\mathrm{Li}$ et al., 2014). In South Korea, reinforced concrete (RC) piles were mainly used from the 1960s to the early 1970s, and prestressed concrete (PC) piles were mainly used from the late 1970s until the early 1990s. However, owing to a growing awareness of safety, an increase in penetration and bearing capacity is required for foundation work. Therefore, pre-tensioned, spun, high-strength concrete (PHC) piles have been put to practical use, replacing the employment of PC piles. Currently, PHC piles represent more than $90 \%$ of the total pile production in South Korea: around 400 to 500 t/year (Park et al., 2008a; Sin et al., 2014). The quality and strength of PHC piles are generally reliable because they are prefabricated in factories. Economic considerations have meant that PHC piles have been applied to most parts of civil structures (Shin et al., 2014). However, PHC piles do have weaknesses, such as resistance to lateral loads and low bearing capacity (Cho, 2007; Jeong et al., 2013). Owing to the limited bearing capacity of PHC piles, the layout of the core part in buildings can become too congested, leading to increases in construction cost and duration, especially for skyscrapers (Lee and Song, 2010).

To address the weaknesses of PHC piles, steel-PHC composite piles, which have high resistance to horizontal forces and bending, have been developed. These steel-PHC piles, also called hybrid composite piles, have been used as a viable replacement for steel piles and PHC piles because of their lower cost and excellent load-bearing capacity (Shin et al., 2014). The substructure of this type of pile is controlled by the PHC pile. Thus, it is difficult 
to obtain the benefits of steel pipe pile, which is of sufficient strength. In general, composite piles are defined as piles consisting of two or more materials. The first composite piles were used in the USA in the 1980s as replacements for timber fender piles at the Port of Los Angeles (Heinz, 1993). Since the application of composite piles, several types of composite piles have been used in many construction sites and have been studied by a great number of researchers. Fibre-reinforced polymer (FRP) piles are another kind of composite pile. Several researchers have carried out theoretical studies on buckling of FRP piles under driving impact and have attempted to experimentally quantify the surface friction between FRP piles and sand (Fam and Rizkalla, 2002; Frost and Han, 1999; Han and Frost, 1999; Mirmiran et al., 2002; Nehdi et al., 2008). Moreover, researchers have analysed the flexural behaviour and strain ductility of FRP piles, and have performed field tests (Li et al., 2011; Mirmiran et al., 1999, 2002; Moran and Pntelides, 2002). Recently, concrete-filled steel tube (CFST) piles have been researched to identify the behaviour of centrally loaded and axially loaded CFSTs, as well as their seismic behaviour (Huo et al., 2009, 2014; Prion and Boehme, 1994; Sakino et al., 2004; Schneider, 1998; Varma et al., 2002).

There is a new type of composite pile called an 'extended end' (Ext) pile, as shown in Figure 1. However, investigations of Ext piles are rare. Only a few studies have been performed, and these have been related to material properties and bearing capacities, validity, effectiveness and the method of construction (Cho, 2007; Jeong et al., 2013; Kim, 2008; Lee and Song, 2010; Lim, 2014; Shin et al., 2014). In addition, most studies have used the material specification of the Ext pile without actual experimentation. However, Ext piles can bring efficiency to pile foundations with respect to time, cost and workability. The overall objective of the present study is to investigate the behaviour of Ext piles.
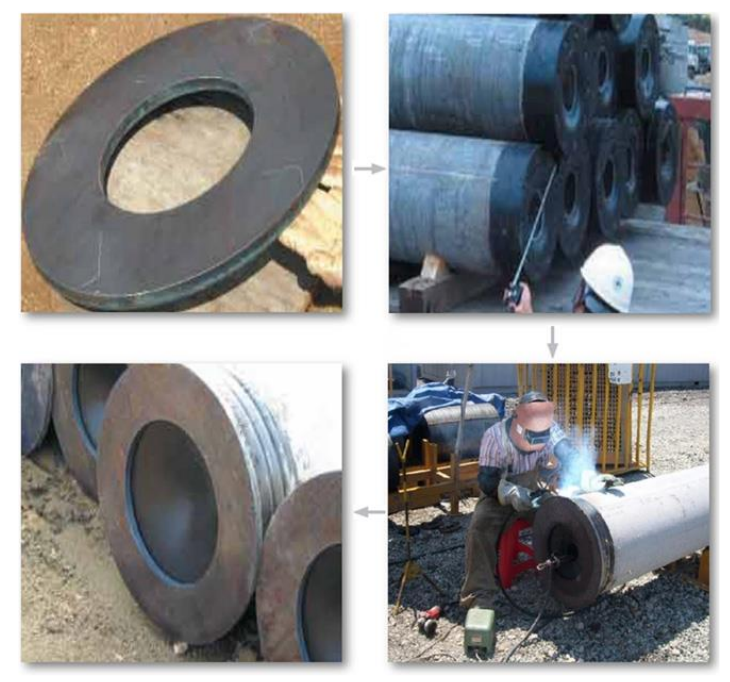

Figure 1. Ext composite pile: (a) extended steel plate; (b) pile dimension check; (c) welding connection; (d) Ext pile

\section{Research methodology}


To verify the economic feasibility of Ext piles, this study used a real construction site. The selected construction site is located in South Korea and is composed of ten apartment buildings with facilities. By using a real case study, various strengths of the Ext pile are demonstrated and compared with the PHC piles that are generally used. A load test was performed between the PHC pile and Ext pile, and the bearing capacity was measured, but seismic issues were not considered because the Korean peninsula is not located in an active seismic area. In addition, to compare the number of Ext and PHC piles, a pile foundation design was carried out. Also, using the pile daily record at the construction site, the project work durations were measured. Finally, this study determined whether the Ext pile foundation work in a construction project was more efficient in terms of time and cost (Figure 2).

\section{Comparison of Ext pile with PHC pile}

\subsection{Allowable bearing capacity}

Generally, a PHC pile is made in a circular pipe shape using pre-stressed steel bars, a reinforcement stirrup and highstrength concrete ( $\mathrm{Li}$ et al., 2014). Approximately $60 \%$ of the pile's strength is used in the design bearing capacity, and the rest simply resides in the ground. Increasing the ground bearing capacity is crucial to reduce any waste of pile strength and to improve efficiency.

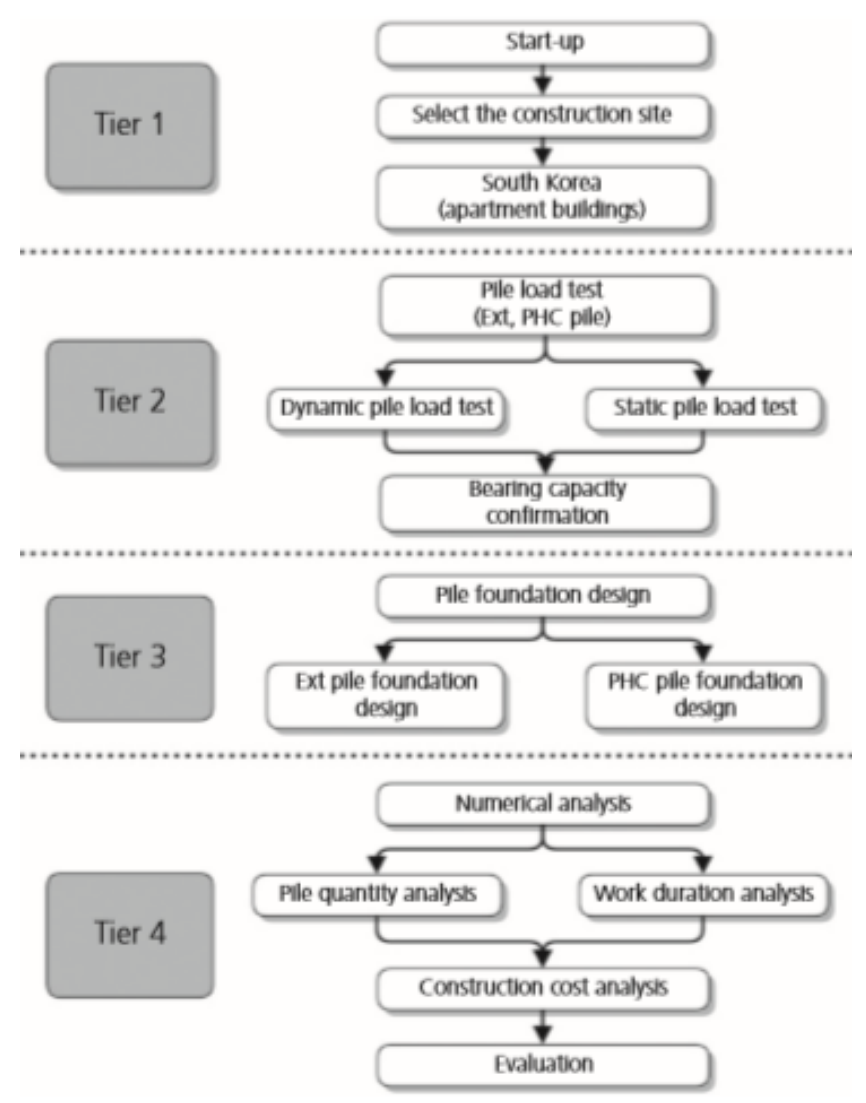

Figure 2. Research procedure 

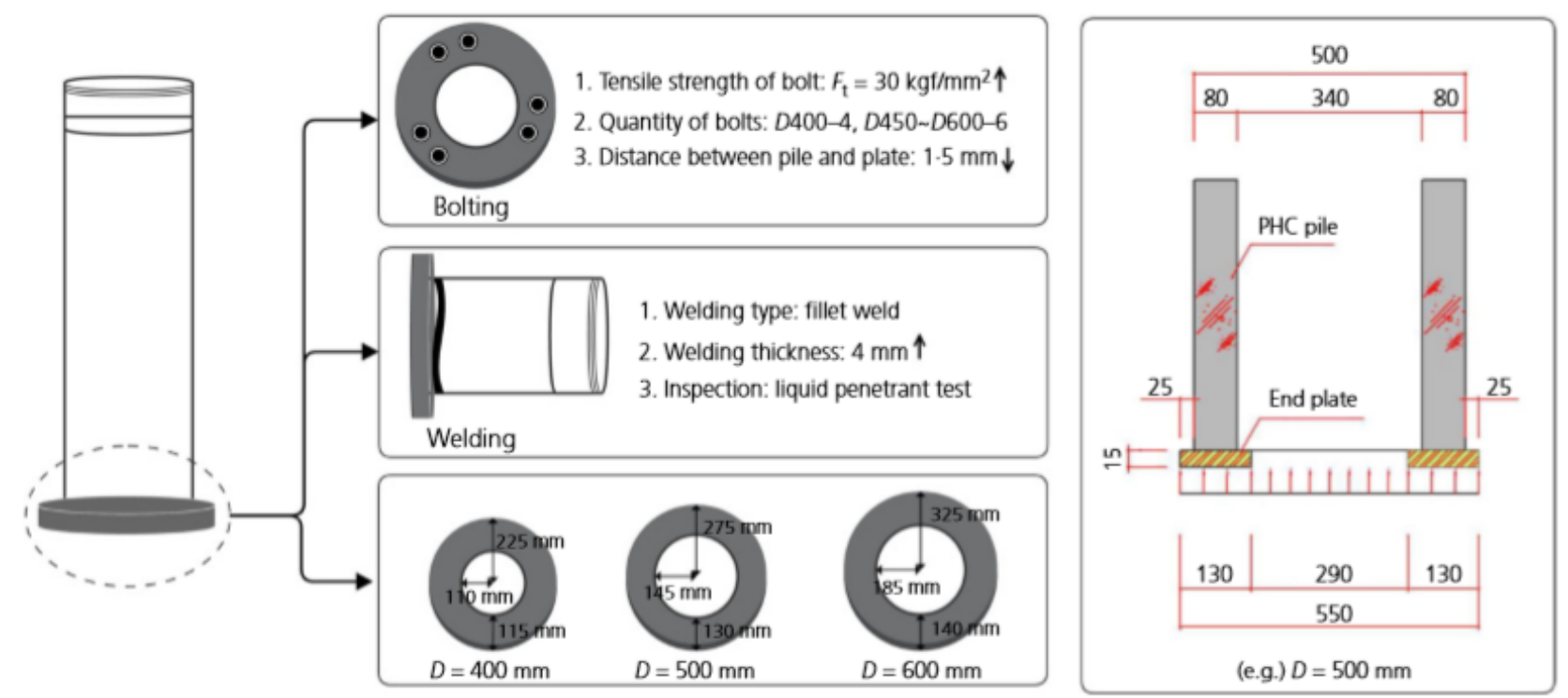

Figure 3. Connection methods and details of the Ext pile (dimensions: $\mathrm{mm}$ )

The Ext pile is capable of overcoming the issue of wasted pile strength that is seen in PHC piles. The Ext pile is a composite pile that combines a PHC pile with an extended steel plate (SS400) on the base. The thickness of the extended end plate is $15 \mathrm{~mm}$ (Kim, 2008). As shown in Figure 3, an Ext pile is made by welding or bolting the extended steel plate to the bottom of PHC pile. An Ext pile has the same skin friction but with increased end bearing capacity compared with a PHC pile of the same shaft diameter and length.

$$
\text { 1. } \mathrm{Fp}=\mathrm{A} \sigma
$$

Equation 1 gives the allowable end bearing capacity, where the endpoint area of the pile (A) is proportional to the allowable bearing capacity (Fp). Thus, because the Ext pile becomes the endpoint area, the value of Fp for the Ext pile is increased, rather than that of the PHC pile. The pile shape is normally circular and the area is calculated using the square of the radius. Thus, a small expansion of the radius leads to a squared term in the area expansion, which strongly affects the value of Fp.

\subsection{Increase in end bearing capacity}

$$
\begin{aligned}
& R=R_{\mathrm{p}}+R_{\mathrm{f}} \\
& R_{\mathrm{p}}=(25 \sim 30) N A_{\mathrm{p}}
\end{aligned}
$$

2. $\quad R_{\mathrm{f}}=f_{\mathrm{s}} A_{\mathrm{b}} l$

$$
\begin{aligned}
& f_{\mathrm{s}}(\text { cohesive soil })=0 \cdot 5 q_{\mathrm{u}}\left(q_{\mathrm{u}}=1.25 \mathrm{~N}\right)=0.625 \mathrm{~N} \\
& f_{\mathrm{s}}(\text { sandy soil })=0.2 \mathrm{~N}
\end{aligned}
$$

Equation 2 shows a bearing capacity formula commonly used in South Korea (Lee and Song, 2010; Lim, 2014; Park et al., 2008a, 2008b). According to Equation 2, the load on the head of a pile (R) is supported by the end bearing capacity (Rp) and by the skin friction (Rf ). From Equation 2, Rp is applied to 25 to 30 multiples of $\mathrm{N}$ 
depending on the soil classification. This range of values covers the construction situation in South Korea, where most piles are constructed with weathered rock layers and the average figure for pile load tests correlates to a range of 25-30N (Lee and Song, 2010). To apply Equation 2 the area is input using units of m2, resulting in values of $\mathrm{Rp}$ and $\mathrm{Rf}$ in units of $\mathrm{kN}$. Also, the magnitude of the standard penetration test $(\mathrm{N})$ has an upper limit of 60. To determine, the value of $\mathrm{Rf}$ a reduction of around 20 to $30 \%$ is also applied in South Korea to consider the uncertainty of soil properties, such as the presence of a gravel layer or the velocity of a moving fluid layer (Lim, 2014).

Table 1 shows pile properties and illustrative end bearing calculation results for both PHC and Ext piles in three pile shaft diameter sizes. Equation 2 has been applied with an allowance for skin friction for a $3 \mathrm{~m}$ long pile in sandy soil. The Appendix also shows an example of how the design bearing capacity has been calculated and shows the factors of safety applied. The $\mathrm{kN}$ values used are 60 for the pile base and 50 for the skin friction.

Table 1 shows the increased endpoint area and design bearing capacity with respect to the shaft diameter of the PHC and Ext piles. The Ext pile end dimensions used are shown in Figure 3. Table 1 shows that the design bearing capacity of the three PHC piles utilises between 51 and $71 \%$ of the pile's proof stress. According to Table 1, the endpoint cross-section and wall thickness of the Ext pile is higher than that of the PHC pile by between 117 and $177 \%$. The design bearing capacity of the Ext pile is able to increase proof stress utilisation to 81 to $94 \%$ for the same shaft diameter. The increased design load due to use of an Ext pile is approximately equivalent to using a PHC pile that is one diameter size greater. The Ext pile, therefore, secures pile foundation stability by extending the end plate to the inside and outside of the pile, as shown in Figure 4.

\begin{tabular}{|c|c|c|c|c|c|c|c|c|c|}
\hline \multirow[b]{2}{*}{$\begin{array}{l}\text { Diameter: } \\
\text { mm }\end{array}$} & \multicolumn{5}{|c|}{ PHC pile } & \multicolumn{3}{|c|}{ Ext pile } & \multirow{2}{*}{$\begin{array}{c}\begin{array}{c}\text { Proportional } \\
\text { increase }\end{array} \\
\text { Cross- section and } \\
\text { wall thickness: \% }\end{array}$} \\
\hline & $\begin{array}{c}\text { Wall } \\
\text { thickness: } \mathrm{mm}\end{array}$ & $\begin{array}{r}\text { Co } \\
\text { secti }\end{array}$ & $\begin{array}{l}\text { te cross- } \\
\text { l area: } \mathrm{m}^{2}\end{array}$ & $\begin{array}{r}\text { Cross } \\
\text { ar }\end{array}$ & $\begin{array}{l}\text { tional } \\
\mathrm{m}^{2}\end{array}$ & $\begin{array}{l}\text { Thickness: } \\
\text { mm }\end{array}$ & $\begin{array}{c}\text { Ext cross- } \\
\text { sectional area: } \mathrm{m}^{2}\end{array}$ & $\begin{array}{c}\text { Cross- sectional } \\
\text { area: } \mathrm{m}^{2}\end{array}$ & \\
\hline D400 & 65 & & 684 & & & 115 & 0.1210 & $0 \cdot 159$ & $127 \sim 177$ \\
\hline D500 & 80 & & 055 & & & 130 & 0.1714 & 0.2375 & $121 \sim 162$ \\
\hline D600 & 90 & & 442 & & & 140 & 0.2242 & 0.3317 & $117 \sim 155$ \\
\hline \multirow[b]{2}{*}{$\begin{array}{l}\text { Diameter: } \\
\text { mm }\end{array}$} & \multirow{2}{*}{\multicolumn{2}{|c|}{$\begin{array}{l}\text { Proof stress } \\
\text { (allowable } \\
\text { axial load): kN }\end{array}$}} & \multicolumn{4}{|c|}{ PHC pile } & \multicolumn{2}{|c|}{ Ext pile } & Increase \\
\hline & & & \multicolumn{2}{|c|}{$\begin{array}{l}\text { Design bearing } \\
\text { capacity: } \mathrm{kN}\end{array}$} & \multicolumn{2}{|c|}{$\begin{array}{l}\text { Proof stress } \\
\text { utilisation: \% }\end{array}$} & $\begin{array}{l}\text { Design bearing } \\
\text { capacity: } \mathrm{kN}\end{array}$ & $\begin{array}{l}\text { Proof stress } \\
\text { utilisation: \% }\end{array}$ & $\begin{array}{l}\text { Proof stress } \\
\text { utilisation: \% }\end{array}$ \\
\hline$D 400$ & 1120 & & \multicolumn{2}{|c|}{$600 \sim 800$} & \multicolumn{2}{|c|}{$54 \sim 71$} & $950 \sim 1050$ & $85 \sim 94$ & $23 \sim 31$ \\
\hline D500 & 1730 & & \multicolumn{2}{|c|}{$1000 \sim 1200$} & \multicolumn{2}{|c|}{$58 \sim 69$} & $1450 \sim 1600$ & $84 \sim 92$ & $23 \sim 26$ \\
\hline D600 & 2360 & & \multicolumn{2}{|c|}{$1200 \sim 1400$} & \multicolumn{2}{|c|}{$51 \sim 59$} & $1900 \sim 2100$ & $81 \sim 89$ & 30 \\
\hline
\end{tabular}

Table 1. Increased endpoint area and design bearing capacity of the Ext pile 

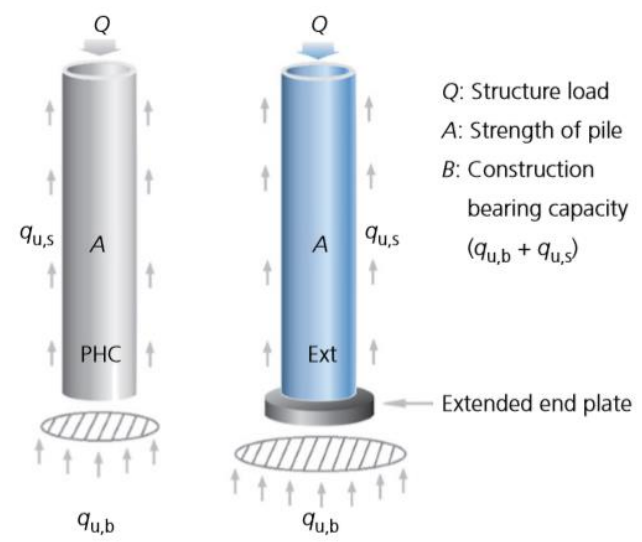

Figure 4. Principle of increased bearing capacity

\section{Field test}

\subsection{Pile load test}

A load test of the pile is used to design or verify the stability of the piles. This test is classified into two types: a dynamic pile load test and a static pile load test. These load tests are highly reliable because they identify bearing capacity by applying a load to the actual pile. The dynamic pile load test can be used to suggest a standard of construction management that is more economical and safe by measuring the bearing capacity and settlement of piles through the use of a pile driving analyser (PDA). The dynamic pile load test is classified as 'end of initial driving (EOID) and restrike'. The EOID is usually conducted after construction or during pile construction by a driveability analysis after measures the driving stresses, impact energy, integrity and end bearing capacity of the pile. The restrike test is conducted after a considerable length of time. Its goals are to verify the effects of changes in the ground (set-up, relaxation) over time, and the calculation of the allowable bearing capacity of pile. The basic principle of the dynamic pile load test is shown in Figure 5.

The purpose of a static pile load test is to determine the bearing capacity of a pile by using a load test that is conducted with an axial pile load. In this research, the plate load test (PLT) system used around the piles was performed as shown in Figure 6. Also, through this system, axial load-settlement (P-S) curves were obtained.

\subsection{Test results}

The construction site for case study is located in South Korea and comprises seven apartment buildings, neighbourhood public facility and common service facilities. The land area and building area of this site are 52 $183000 \mathrm{~m} 2$ and $8929873 \mathrm{~m} 2$, respectively. To verify detailed soil conditions about the testing site, a standard penetration test was conducted, with selected results shown in Figure 7, and pile installation was conducted based on the test results. Around $18661617 \mathrm{~m} 2$ of the land area was required piling for foundations owing to the insufficient bearing capacity of the soil determined through field load testing. The standard pile size used on this construction site was $\mathrm{D}=500 \mathrm{~mm}$, a shaft wall thickness of $80 \mathrm{~mm}$ and concrete compressive strength was $78 \cdot 5$ $\mathrm{N} / \mathrm{mm} 2(800 \mathrm{~kg} / \mathrm{cm} 2)$. Drop- $4 \cdot 0 \mathrm{t}$ hammers were used for the pile driving load test. The design bearing capacity of these areas is $1200 \mathrm{kN}$ in the PHC pile and $1600 \mathrm{kN}$ in the Ext pile per unit. 


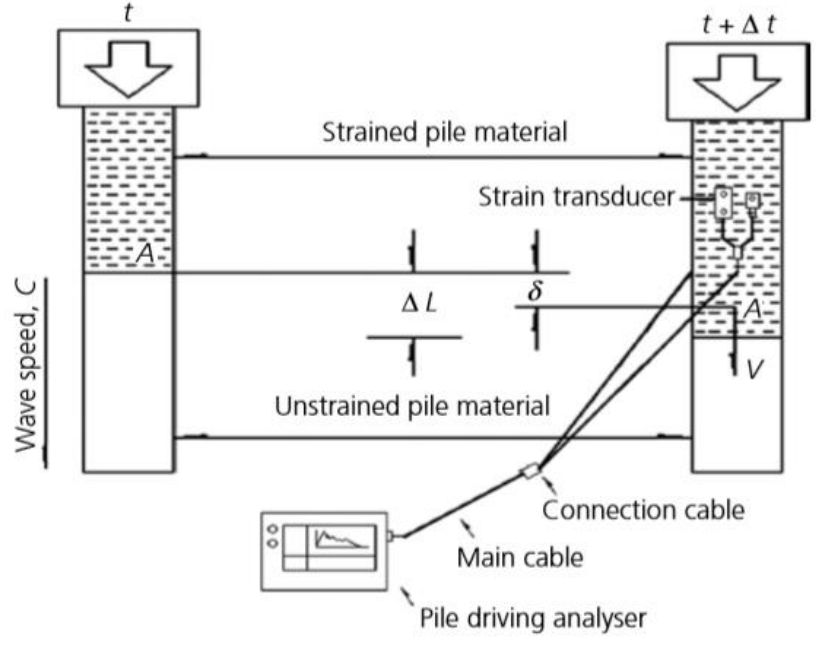

(a)

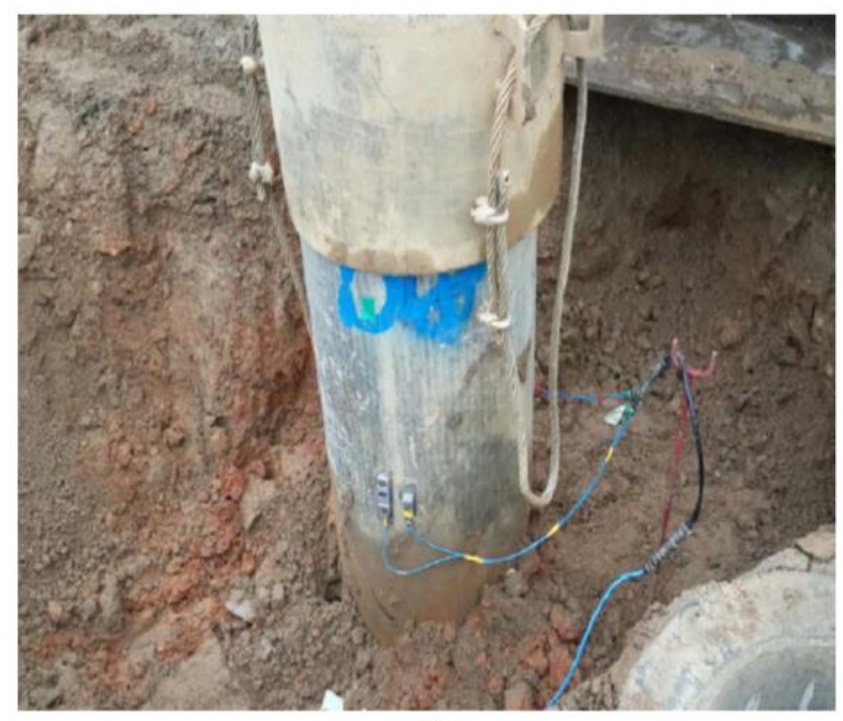

(b)

Figure 5. Dynamic pile load system: (a) schematic diagram; (b) installation

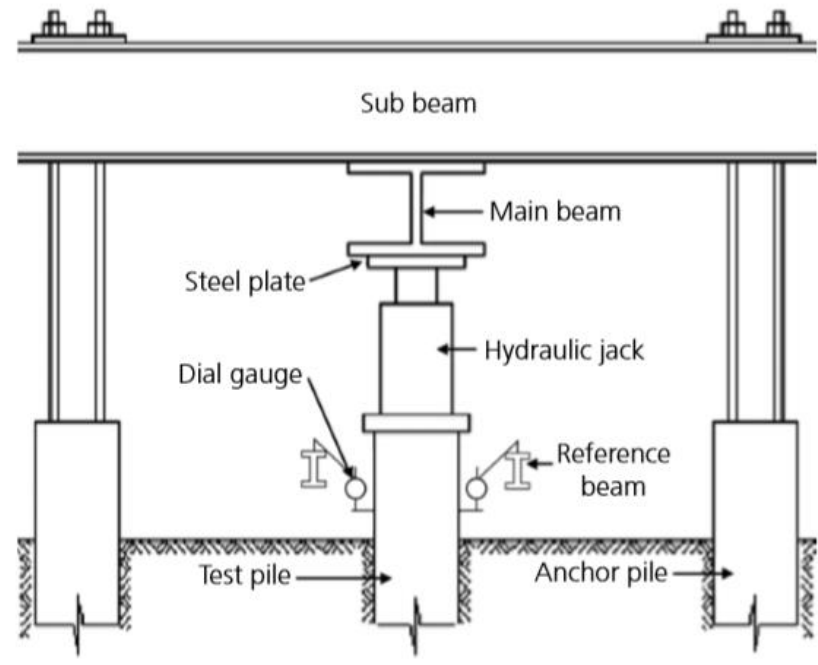

(a)

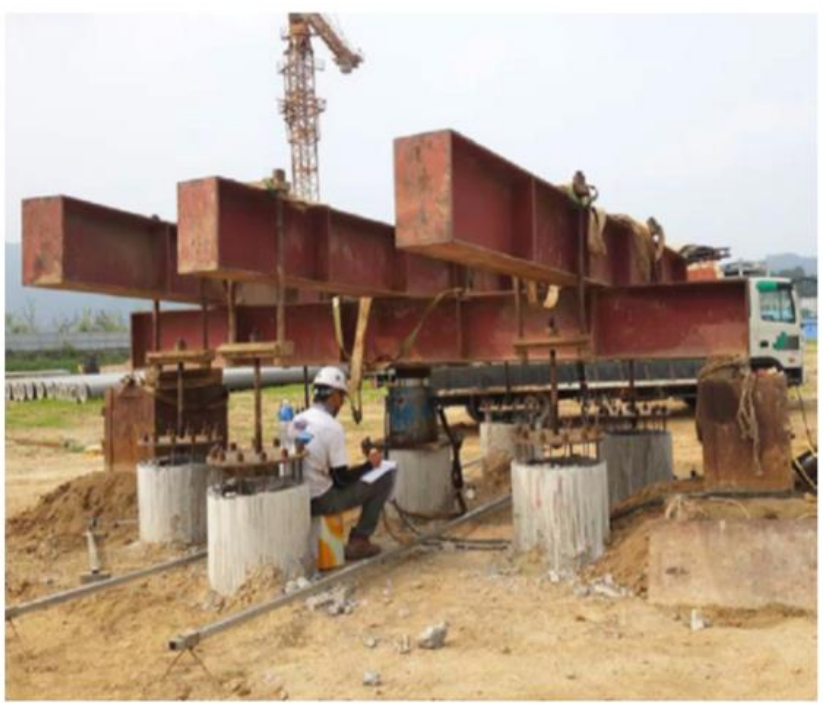

(b)

Figure 6. Plate load test system used around piles: (a) schematic diagram; (b) installation

The test piles, both Ext and PHC, were constructed using the separated doughnut auger (SDA) method and a driving procedure has been added in Figure 8. The SDA piling method is to drill the ground with the upper continuous flight auger and the lower casing, rotating counter to each other, and to rotate and push or drive lightly after a pre-cast pile is inserted. The SDA piling method is a solution to the low bearing capacity of the pile and the stress relaxation, which are common problems in other piling methods (Chai, 2000; Hong and Chai, 2003). As shown in Figure 8, Ext piles were reinforced by cement milk grouting around in increased installation diameter 
comprising the extended end plate. Therefore, the end plate does not disturb the soil during pile installation. Also, to avoid overstress and damage to the pile, the weight of hammer applied was determined as shown in Figure 9.

As shown in Table 2, the test results of the allowable bearing capacity of the Ext pile are 1956.08, 1921.58, $1870 \cdot 23$ and $1939.62 \mathrm{kN}$, respectively. Thus, the overall value is $1921.88 \mathrm{kN}$. The PHC pile results are $1497 \cdot 83$, $1560.94,1251.66$ and $1382.98 \mathrm{kN}$. Thus, this study obtained an overall value of $1423.35 \mathrm{kN}$. Based on the test result, it was determined that the allowable bearing capacity of the Ext pile is on average $35 \%$ higher than that of the PHC pile. The static pile load test requires $225 \%$ of the maximum possible load design. Therefore, $3600 \mathrm{kN}$ was determined to be the maximum load, and the loading test was conducted after eight load steps. Moreover, in each load step, the load was maintained until the rate of settlement was $0 \cdot 25 \mathrm{~mm} / \mathrm{h}$ or under, and for less than $2 \mathrm{~h}$. Figure 10 shows the results of the static pile load test. As shown in Figure 10(a), the P-S curve of the Ext pile shows that the settlement regularly increased in each step until $3600 \mathrm{kN}$. Thus, the allowable bearing capacity of the Ext pile with a safety factor of 2.0 was determined to be $1800 \mathrm{kN}$ ". In the case of the PHC pile, the designed load test was also applied until $2700 \mathrm{kN}$, which is $225 \%$ of the maximum possible load design of $1200 \mathrm{kN}$. As a result, the allowable bearing capacity was found to be $1350 \mathrm{kN}$ " (137.66 tf) after applying a safety factor of 2.0.

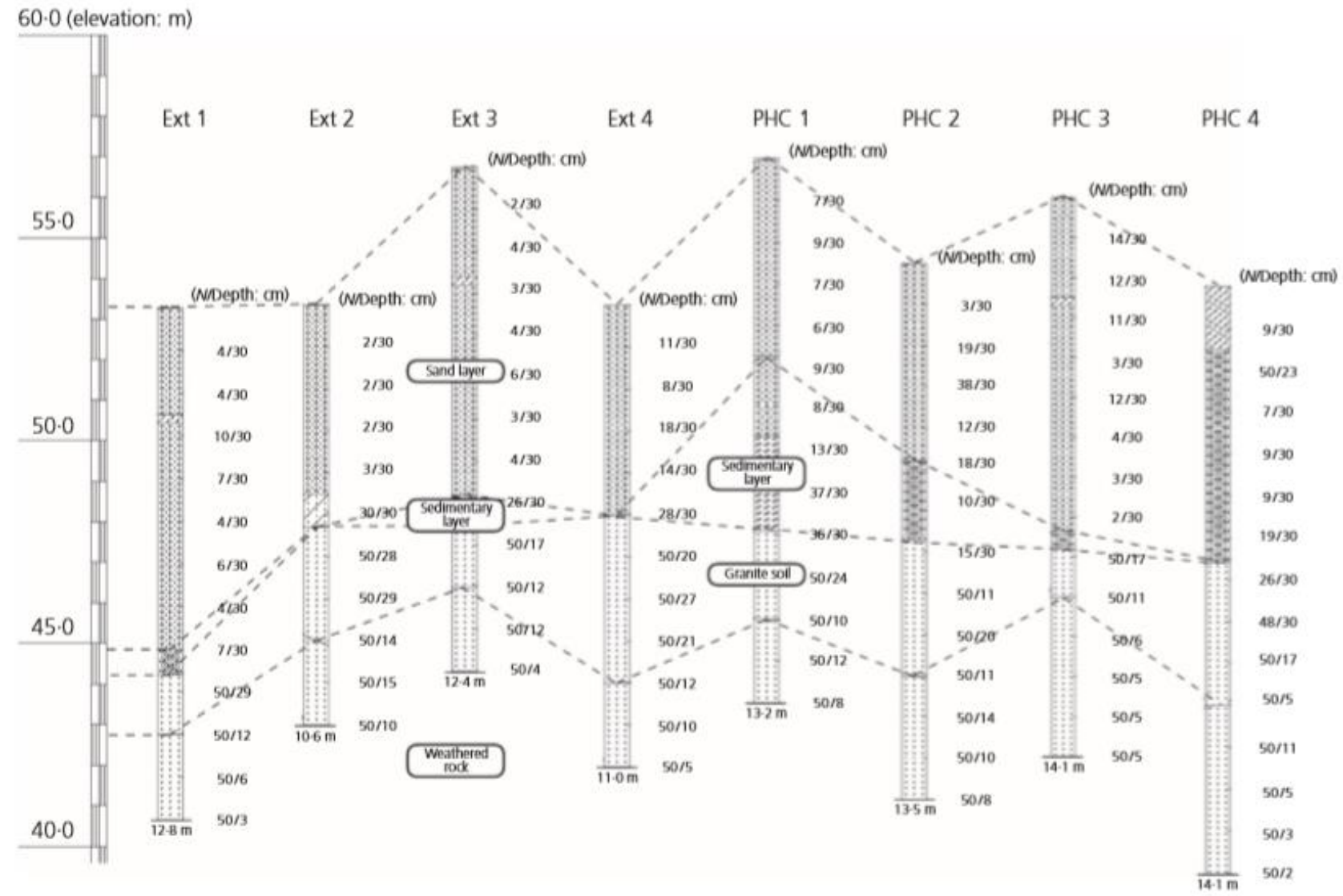

Figure 7. Standard penetration test at selected locations of the site 


\section{Cost analysis}

\subsection{Pile quantities}

Through the pile load test, it was confirmed that the bearing capacity of the Ext pile is better than the PHC pile. Thus, it is possible to increase the design load in the pile design step. Next, this study compared the number of piles between the Ext piles and PHC piles through the design of the pile foundation. The load is delivered by the wall to the piles through the foundation, and the piles transfer the load to the ground. Therefore, a low bearing capacity is required to a quantity of many piles, but a high bearing capacity leads to the opposite result. Using this principle and the pile load test results, a pile foundation design carried out.

The differences of the basic designs between the PHC pile and Ext pile are shown in Figure 11. With PHC piles, the pile design should be arranged in two columns in order to support the load of the building because a large number of piles should be arranged within a limited space as shown in Figure 11(c). In contrast, an Ext pile is able to arrange one column on the lower part of a vertical wall because the pile quantities are decreased as shown in Figure 11(d). Therefore, the pile design between PHC and Ext piles is totally different. In the case of a wall foundation, four PHC piles should be constructed to endure the load of a structure, but only two Ext piles can withstand the same load of the four PHC piles as shown in Figures 11(c) and 11(d). For an isolated foundation, five PHC piles must be constructed per location, while only three Ext piles can withstand the same load as shown in Figures 11(a) and 11(b). These pile foundation designs were carried out based on structural calculations. Through this basic design, pile foundation design was conducted for the applied construction site. When PHC piles were used for the pile foundation design, a total of 2337 PHC piles were used whereas the Ext pile design used only 1683 piles. Therefore, the Ext pile design reduced the number of piles by around $38 \%$ compared to the PHC pile design.

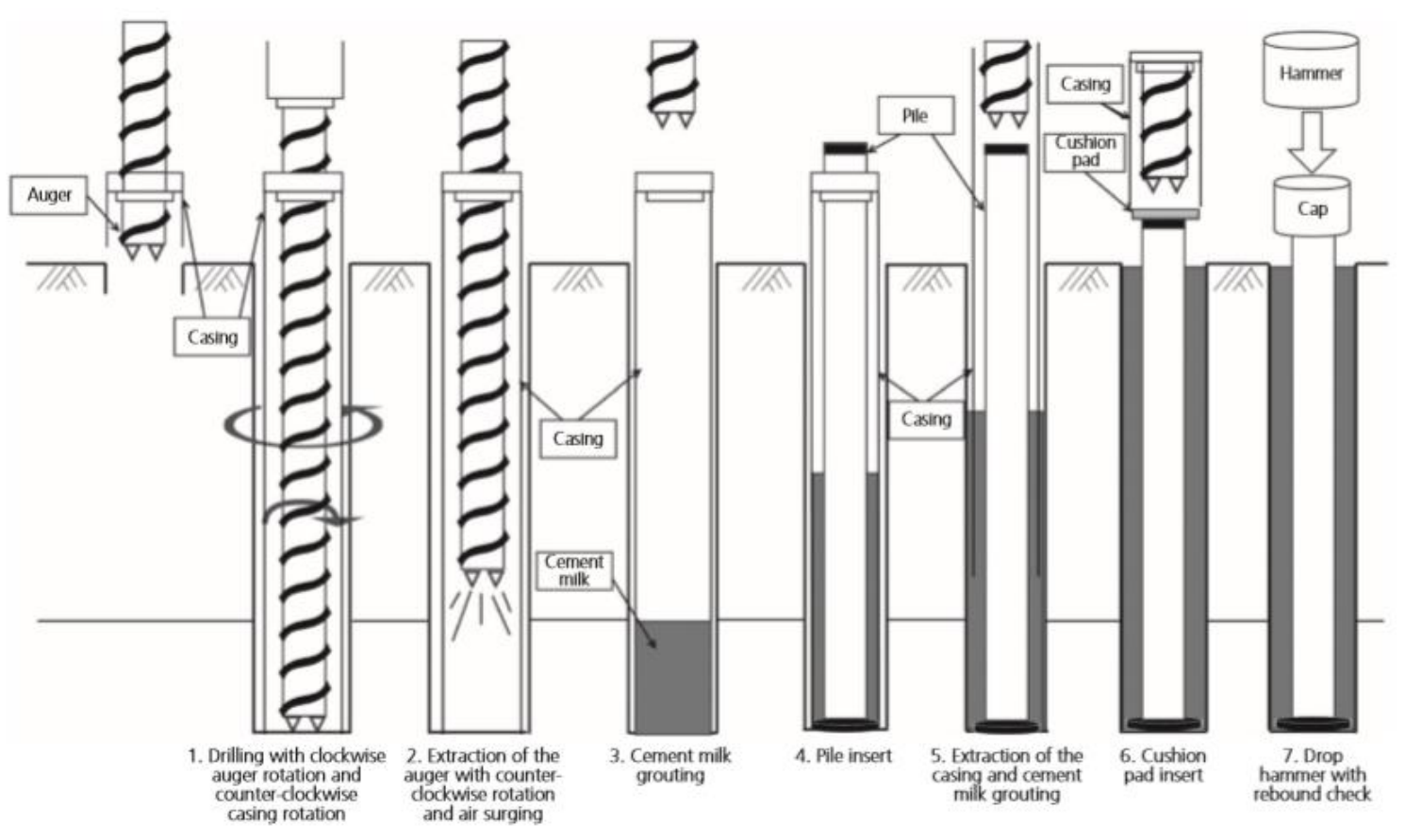

Figure 8. SDA procedure 


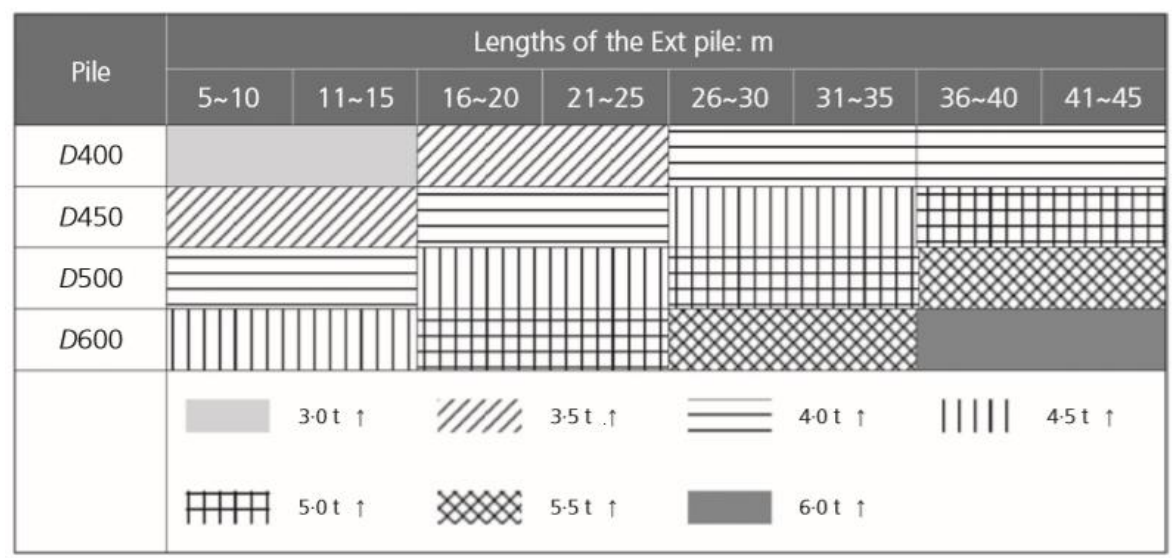

Figure 9. Hammer standards

\subsection{Work duration}

Through the comparison of the Ext and PHC pile foundation designs, this study determined that one advantage of the Ext pile is the decreased number of piles required. However, there is another advantage of the Ext pile in terms of the project's duration. Normally, the duration of the pile foundation work is influenced by the number of piles. Thus, the reduction of the pile quantity results in a reduction in the project duration, especially in pile foundation work. To evaluate this effect, a duration assessment of the pile foundation work was conducted by calculating the quantity of Ext and PHC piles. Using the pile daily record of the Ext pile in the selected construction site, the duration was calculated to be $57 \mathrm{~d}$ using two pile-driving machines. Therefore, it is confirmed that an average of 15 piles can be constructed per day using one piledriving machine to drive 1683 piles. Using this calculation method, the pile foundation work duration of the PHC pile was also measured.

\begin{tabular}{|c|c|c|c|c|c|c|c|c|}
\hline \multirow[b]{2}{*}{$\begin{array}{l}\text { Pile } \\
\text { no. }\end{array}$} & \multirow[b]{2}{*}{$\begin{array}{c}\text { Depth of } \\
\text { penetration: } m\end{array}$} & \multicolumn{3}{|c|}{ Capwap capacity: kN } & \multicolumn{2}{|c|}{ Allowable bearing capacity: $\mathrm{kN}$} & \multirow[b]{2}{*}{$\begin{array}{l}\text { Final allowable } \\
\text { bearing capacity: } \mathrm{kN}\end{array}$} & \multirow[b]{2}{*}{ Division } \\
\hline & & $\begin{array}{l}\text { Skin friction } \\
\text { force }\end{array}$ & $\begin{array}{l}\text { End bearing } \\
\text { capacity }\end{array}$ & $\begin{array}{c}\text { Whole } \\
\text { supporting force }\end{array}$ & $\begin{array}{l}\text { Capwap } \\
(\mathrm{FS}=2 \cdot 5)\end{array}$ & $\begin{array}{l}\text { Davisson } \\
(\mathrm{FS}=2 \cdot 0)\end{array}$ & & \\
\hline \multirow[t]{2}{*}{ PHC 1} & $13 \cdot 2$ & 8.82 & $3662 \cdot 26$ & 3671.08 & 1468.432 & $1836 \cdot 52$ & - & EOID \\
\hline & & $401 \cdot 8$ & $3342 \cdot 78$ & 3744.58 & 1497.832 & 1870.82 & 1497.83 & Restrike \\
\hline \multirow[t]{2}{*}{ PHC 2} & $13 \cdot 5$ & 251.86 & $3560 \cdot 34$ & $3812 \cdot 2$ & 1524.88 & $1804 \cdot 18$ & - & EOID \\
\hline & & 674.24 & 3230.08 & $3902 \cdot 36$ & 1560.944 & $1841 \cdot 42$ & 1560.94 & Restrike \\
\hline \multirow[t]{2}{*}{ PHC 3} & $14 \cdot 1$ & 0.98 & $3004 \cdot 68$ & $3005 \cdot 66$ & $1202 \cdot 264$ & $986 \cdot 37$ & - & EOID \\
\hline & & $595 \cdot 84$ & $2480 \cdot 38$ & 3135.02 & 1251.656 & 1151.01 & $1251 \cdot 66$ & Restrike \\
\hline PHC 4 & & $709 \cdot 52$ & 2747.92 & 3457.44 & 1382.976 & 1422.47 & 1382.98 & Restrike \\
\hline \multirow[t]{2}{*}{ Ext 1} & $12 \cdot 8$ & 413.56 & 4118.94 & 4118.94 & 1647.576 & 2059.47 & - & EOID \\
\hline & & 988.82 & $3901 \cdot 38$ & $4890 \cdot 2$ & 1956.08 & $2444 \cdot 12$ & 1956.08 & Restrike \\
\hline \multirow[t]{2}{*}{ Ext 2} & $10 \cdot 6$ & $88 \cdot 2$ & 4174.8 & 4263 & $1705 \cdot 2$ & 2448.04 & - & EOID \\
\hline & & $855 \cdot 54$ & 3948.42 & 4803.96 & 1921.584 & 2411.78 & 1921.58 & Restrike \\
\hline \multirow[t]{2}{*}{ Ext 3} & $12 \cdot 4$ & $89 \cdot 18$ & 4362.96 & $4452 \cdot 14$ & $1780 \cdot 856$ & $2093 \cdot 28$ & - & EOID \\
\hline & & $645 \cdot 82$ & 4028.78 & $4675 \cdot 58$ & $1870 \cdot 232$ & $2101 \cdot 218$ & $1870 \cdot 23$ & Restrike \\
\hline \multirow[t]{2}{*}{ Ext 4} & 11.0 & $237 \cdot 16$ & $4095 \cdot 42$ & $4332 \cdot 58$ & 1733.032 & 2071.72 & - & EOID \\
\hline & & 463.54 & $4384 \cdot 52$ & 4849.04 & 1939.616 & $2059 \cdot 764$ & 1939.62 & Restrike \\
\hline
\end{tabular}

Table 2. Dynamic pile load test result

Through the field test, this study verified that the construction of an average of 15 piles is possible per day using one piledriving machine at the selected construction site. Therefore, a work duration of 2337 PHC piles requires 
around $156 \mathrm{~d}$ when using one pile-driving machine, and this will be reduced by half (to around $78 \mathrm{~d}$ ) when two pile-driving machines are used. According to the test results, the Ext pile has a time advantage in that its use can decrease the required construction time by $36 \%$ in pile foundation work in comparison with the PHC pile. However, at the selected construction site, two pile-driving machines were used in view of the scale of the construction site and process planning. Thus, the duration of pile foundation work between the Ext and PHC piles is 57 and $78 \mathrm{~d}$, respectively, as shown in Table 3 . Through this test result, it can be seen that the increased bearing capacity of the Ext pile leads to a reduction in the number of piles and the duration of work. From this study, it is anticipated that these effects will be greater for a large-scale construction site or in adverse soil conditions.

\subsection{Construction costs}

The advantage of Ext pile construction is closely related to the construction cost. To verify this, the pile foundation costs of the selected construction site were analysed through the related construction costs. The cost of pile foundation work is normally based on the materials used, pile driving work, pile cutting work, and the static and dynamic pile load testing. Therefore, a comparison between the Ext pile and the PHC pile was carried out to in order to understand the cost benefits.

As shown in Table 4, the pile cutting work cost was observed to be the biggest reduction, with around a decrease of around $28 \%$. Moreover, the pile-driving work and material cost also decreased by around $27 \%$ and $9 \cdot 3 \%$, respectively. Therefore, this study confirmed that Ext pile construction can decrease the cost of pile foundation work by approximately $15 \cdot 4 \%$ compared with PHC pile construction.

\section{Conclusions}

In this study, a new composite pile called the 'Ext pile' was proposed for pile foundation work in a real construction project. The Ext pile method was applied to a construction site to determine its various effects. First, a pile load test was conducted at a selected construction site in order to determine the bearing capacity of the Ext piles. Then, the study confirmed that the bearing capacity of the Ext pile was better than that of the PHC piles by, on average, $35 \%$. Based on these test results, the pile foundation design saved a significant number of piles by using Ext piles in place of PHC piles. Finally, this study confirmed that the Ext pile is efficient in terms of time and cost. On the basis of these findings, the following conclusions are drawn. 

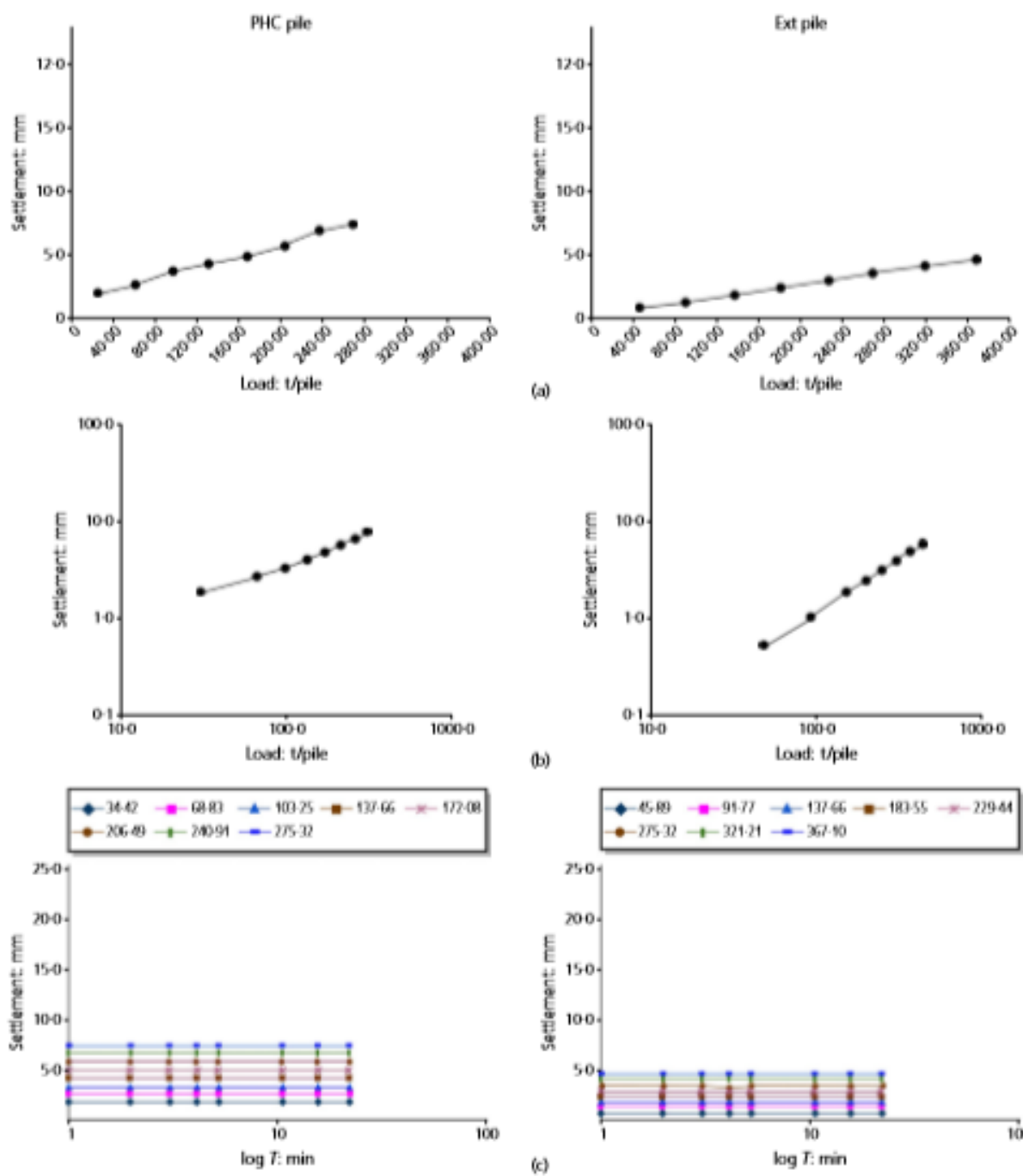

(b)

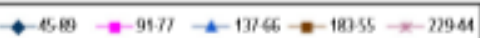
$-2532+-32124-37.50$

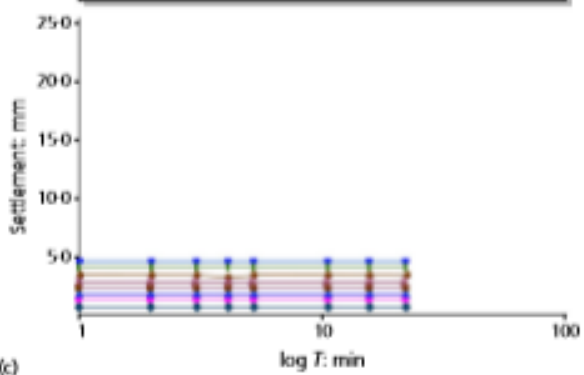

Figure 10. Pile load tests: (a) P-S curve; (b) $\log \mathrm{P}-\operatorname{logS}$ curve; (c) S-logT curve
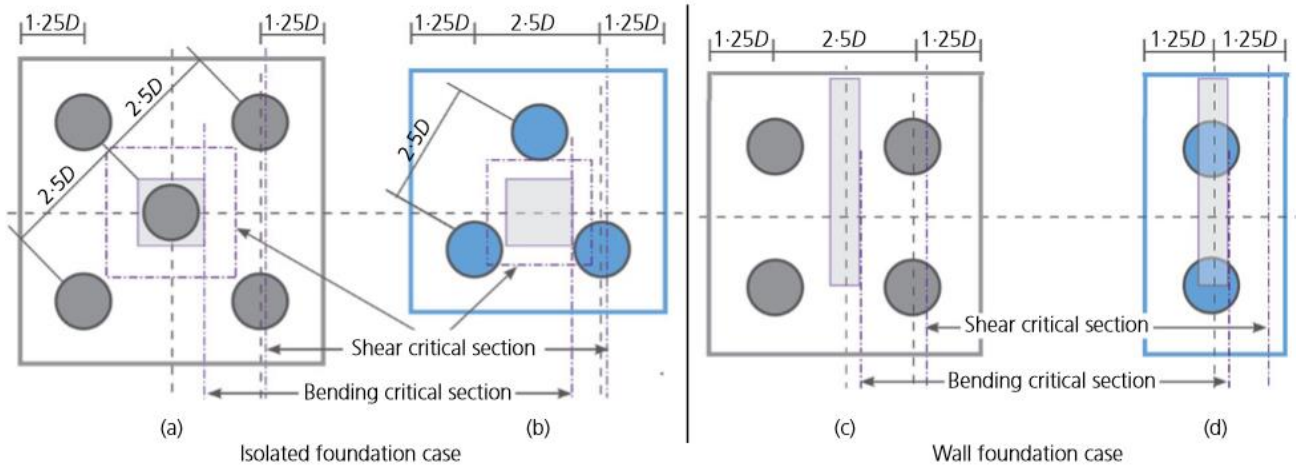

Figure 11. Comparison of pile foundation designs: isolated foundation case for (a) PHC pile; (b) Ext pile; and wall foundation case for (c) PHC pile; (d) Ext pile 
(a) Ext piles can be used more effectively in congested areas because of the increased bearing capacity per unit due to the extended steel end plate. In this study, a reduction of piles of approximately $38 \%$ was confirmed at an actual construction site.

\begin{tabular}{|lccccccc|}
$\begin{array}{l}\text { Pile } \\
\text { types }\end{array}$ & $\begin{array}{c}\text { Pile diameter: } \\
\mathbf{m m}\end{array}$ & $\begin{array}{c}\text { Design bearing } \\
\text { capacity: } \mathbf{k N}\end{array}$ & $\begin{array}{c}\text { Pile } \\
\text { quantity: ea }\end{array}$ & $\begin{array}{c}\text { Total pile } \\
\text { length: } \mathbf{m}\end{array}$ & $\begin{array}{c}\text { Pile-driving } \\
\text { machine: ea }\end{array}$ & $\begin{array}{c}\text { Working } \\
\text { duration: } \mathbf{d}\end{array}$ & $\begin{array}{c}\text { Duration } \\
\text { shortened by: } \mathbf{d}\end{array}$ \\
\hline PHC & 500 & 1200 & 2337 & 25357 & 2 & 78 & - \\
Ext & 500 & 1600 & 1683 & 18258 & 2 & 57 & 21 \\
\hline
\end{tabular}

ea, each number

Table 3. Comparison of work duration

\begin{tabular}{|c|c|c|c|c|c|c|c|c|}
\hline \multirow[b]{2}{*}{ Cost types } & \multicolumn{3}{|c|}{ PHC pile (D500) } & \multicolumn{3}{|c|}{ Ext pile (D500) } & \multirow[b]{2}{*}{$\begin{array}{l}\text { Difference: } \\
\text { US\$ }\end{array}$} & \multirow[b]{2}{*}{ Reduction: \% } \\
\hline & Quantity & $\begin{array}{l}\text { Unit: } \\
\text { US\$ }\end{array}$ & $\begin{array}{l}\text { Total: } \\
\text { US\$ }\end{array}$ & Quantity & $\begin{array}{l}\text { Unit: } \\
\text { US\$ }\end{array}$ & $\begin{array}{l}\text { Total: } \\
\text { US\$ }\end{array}$ & & \\
\hline Materials $^{\mathrm{a}}$ & 2337 ea $(25357 \mathrm{~m})$ & 27 & 684640 & 1683 ea $(18258 \mathrm{~m})$ & 34 & 620772 & -63868 & $-9 \cdot 3$ \\
\hline Construction $^{\mathrm{b}}$ & $78 \mathrm{~d}$ & $2210 \times 2^{c}$ & 344760 & $57 \mathrm{~d}$ & $2210 \times 2^{c}$ & 251940 & -92820 & -27 \\
\hline Pile head cutting & 2337 ea & $7 \cdot 3$ & 17060 & 1683 & $7 \cdot 3$ & 12286 & -4774 & -28 \\
\hline & & 1046460 & & & 884998 & & -161462 & $-15 \cdot 4$ \\
\hline
\end{tabular}

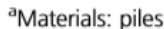

${ }^{\mathrm{b} C o n s t r u c t i o n: ~ p i l e ~ d r i v e r, ~ b a c k h o e, ~ s i l o, ~ p a y ~ l o a d e r, ~ g e n e r a t o r, ~ l a b o u r ~}$

${ }^{\mathrm{c}} 2$ : two pile drivers

Table 4. Comparison of work costs

\begin{tabular}{llcc} 
Pile & & PHC pile & Ext pile \\
\hline Diameter: $\mathrm{mm}$ & & 500 & 500 \\
Cross-sectional area $\left(A_{\mathrm{p}}\right): \mathrm{m}^{2}$ & & $0 \cdot 1963$ & $0 \cdot 2375$ \\
Pile principal plane length $\left(A_{\mathrm{b}}\right): \mathrm{m}$ & & $3 \cdot 14$ & $3 \cdot 454$ \\
Pile length $(I): \mathrm{m}$ & $25 \times N \times A_{\mathrm{p}}(N=60)$ & 3 & 3 \\
End bearing capacity $\left(R_{\mathrm{p}}\right): \mathrm{kN}$ & $f_{\mathrm{s}} \times A_{\mathrm{b}} \times I$ & $2885 \cdot 61$ & $3491 \cdot 25$ \\
Skin friction $\left(R_{\mathrm{f}}\right): \mathrm{kN}$ & $f_{\mathrm{s}}=0 \cdot 2 \times N($ sandy soil $)(N=50)$ & $923 \cdot 16$ & $1015 \cdot 476$ \\
& 1 & 3 & 3 \\
Safety factor, $n$ & $\frac{1}{n} \times\left(R_{\mathrm{p}}+R_{\mathrm{f}}\right)$ & $1269 \cdot 59$ & $1502 \cdot 24$ \\
Design bearing capacity: $\mathrm{kN}$ & & & \\
\hline
\end{tabular}

Table 5. Example design bearing capacity calculation using Equation 2

(b) The reduced number of piles also leads to a reduction in work duration. At the field site, it was determined that the pile foundation work using the Ext piles required $57 \mathrm{~d}$, whereas using the PHC piles required $78 \mathrm{~d}$. Thus the use of Ext piles reduced the work duration by a total of $21 \mathrm{~d}$. The effect of this reduction in work duration will be higher at a large-scale construction site or under adverse soil conditions.

(c) The advantage of the Ext pile also manifested in terms of the construction cost. Based on the results of the study site, using Ext piles reduced the cost of the foundation work by approximately $15 \cdot 4 \%$ compared to the use of PHC piles. 


\section{Appendix}

See Table 5 for an example of the design bearing capacity calculation.

\section{REFERENCES}

Chai SG (2000) SDA piling method (Seoul-Busan high speed rail project). Civil Engineering Journal of the Korean Society of Civil Engineers 48(9): 54-62.

Cho DJ (2007) Research on a Case Study Analysis of EXT-PIE Method of Construction in Apartment Housing. MSc dissertation, Hanyang University, Seoul, South Korea.

Fam AZ and Rizkalla SH (2002) Flexural behavior of concrete-filled fiber-reinforced polymer circular tubes. Journal of Composites for Construction ASCE 6(2): 123-132.

Frost JD and Han J (1999) Behavior of interfaces between fiber-reinforced polymers and sands. Journal of Geotechnical and Geoenvironmental Engineering 125(8): 633-640.

Han J and Frost JD (1999) Buckling of vertically loaded fiber-reinforced polymer piles. Journal of Reinforced Plastics and Composites 18(4): 290-318.

Heinz R (1993) Plastic piling. Civil Engineering 63(4): 63-65.

Hong WP and Chai SG (2003) The skin friction capacity of SDA (separated doughnut auger) pile. Proceedings of the $13^{\text {th }}$ International Offshore and Polar Engineering Conference (Matsui T, Chung JS, Sayed M and Wong PC (eds)). International Society of Offshore and Polar Engineers, Mountain View, CA, USA, vol. II, pp. 740-765.

Huo J, Zheng Q, Chen B and Xiao Y (2009) Tests on impact behaviour of micro-concrete-filled steel tubes at elevated temperatures up to $400^{\circ} \mathrm{C}$. Materials and Structures 42(10): 1325-1334.

Huo J, He Y and Chen B (2014) Experimental study on impact behavior of concrete-filled steel tubes at elevated temperatures up to $800^{\circ} \mathrm{C}$. Materials and Structures 47(1-2): 263-283.

Jeong M, Cho J, Kim S and Choi B (2013) The test construction case of EXT-Pile. Journal of the Korean Geotechnical Society 29(2): 10-20.

Kim SI (2008) A Study on the Point Bearing Capacity Increase of PHC Piles with an Extended Head. MSc dissertation, Seoul National University of Science and Technology, Seoul, South Korea.

Lee JS and Song KY (2010) Material properties and bearing capacities of extended PHC pile with enlarged pile thickness. Journal of the Architectural Institute of Korea 30(1): 207-208.

Li G, Pang SS and Ibekwe SI (2011) FRP tube encased rubberized concrete cylinders. Materials and Structures 44(1): 233-243. 
Li GW, Pei HF, Yin JH, Lu XC and Teng J (2014) Monitoring and analysis of PHC pipe piles under hydraulic jacking using FBG sensing technology. Measurement 49: 358-367.

Lim CB (2014) Research through Case Study: Cost Reduction Effect of EXT-Pile Construction Sites. MSc dissertation, Korea University, Seoul, South Korea.

Mirmiran A, Shahawy M and Samaan M (1999) Strength and ductility of hybrid FRP concrete beamcolumns. Journal of Structural Engineering 125(10): 1085-1093.

Mirmiran A, Shao Y and Shahawy M (2002) Analysis and field tests on the performance of composite tubes under pile driving impact. Composite Structures 55(2): 127-135.

Moran DA and Pntelides CP (2002) Variable strain ductility ratio for fiber-reinforced polymer-confined concrete. Journal of Composites for Construction ASCE 6(4): 224-232.

Nehdi M, Omeman Z and El-Chabib H (2008) Optimal efficiency factor in strut-and-tie model for FRPreinforced concrete short beams with $(1.5<\mathrm{a} / \mathrm{d}<2.5)$. Materials and structures 41(10): 1713-1727.

Park TK, Lee JC and Lee CS (2008a) Problem and improvement measure of PHC pile construction. Korea Journal of Construction Engineering and Management 11: 347-352.

Park JB, Lim HS and Park YB (2008b) Design and load test criteria of SIP at Korea National Housing Corporation. In Proceedings of the Fall National Conference. Korean Geotechnical Society, Seoul, Korea, pp. 533-540.

Prion HG and Boehme J (1994) Beam-column behavior of steel tubes filled with high strength concrete. Canadian Journal of Civil Engineering 21(2): 207-218.

Sakino K, Nakahara H, Morino S and Nishiyama I (2004) Behavior of centrally loaded concrete-filled steeltube short columns. Journal of Structural Engineering 130(2): 180-188.

Schneider S (1998) Axially loaded concrete-filled steel tube. Journal of Structural Engineering 124(10): 1125-1138.

Shin Y, Kim M, Ko J and Jeong S (2014) Proposed design chart of mechanical joints on steel-PHC composite piles. Materials and Structures 47(7): 1221-1238.

Sin H, Lim JH and Heo GS (2014) The feasibility assessment of the extended end PHC pile using finite element analysis. Journal of the Korea Structural Engineers Association 21(4): 31-37.

Tomlinson M and Woodward J (2014) Pile Design and Construction Practice. CRC Press, New York, NY, USA. 
Varma AH, Ricles JM, Sause R and Lu LW (2002) Seismic behavior and modeling of high-strength composite concrete-filled steel tube (CFT) beam-columns. Journal of Construction Steel Research 58(5-8): $725-758$. 